\title{
Councils, Counsel and the Seventeenth-Century Composite State*
}

\section{JACQUELINE ROSE}

In the closing pages of his treatise 'Of the union of Britayne', the Presbyterian clergyman Robert Pont sought to reassure his fellow Scots and English neighbours that a union of their kingdoms merely enlarged and would not change their commonwealth. 'If any small differences arise', Pont blithely declared, 'they wil be by sage counsel easily reconcyled'. ${ }^{1}$ In the honeymoon days of 1604, when James VI's accession to the throne of England seemed to promise the fulfilment of God's plan for a Protestant British imperium, Pont's optimism was excusable. His reticence in spelling out the details of joint or coordinate British conciliar mechanisms was, in part, a typical humanist adherence to the moral economy of counsel which floated loftily above institutional specificities. Pont's interlocutors express admiration for a princely commonwealth which is tempered by aristocracy. Both England and Scotland avoided the risk of tyranny by founding their commonwealths 'upon such a ground, where one kinge by the counsell of his nobility ruled all'.2 This was less English ancient constitutionalism than Scottish aristocratic conciliarism. But Pont's silence on the details of British councils was typical of many writers in the Jacobean union debates and beyond.

\footnotetext{
* My thanks to all those who commented on drafts of this article.

${ }^{1}$ The Jacobean Union: Six Tracts of 1604, ed. B. R. Galloway and B. P. Levack (Edinburgh, Scottish History Society, 4th ser., 21, 1985), p. 24.

${ }^{2}$ Jacobean Union: Six Tracts, pp. 1-2.
} 
That the seventeenth-century Atlantic archipelago was plagued by the problem of being a composite state is well known. 'The British problem' both exacerbated and was fuelled by questions about religion, law, trade and the extent and nature of royal authority. There were repeated attempts to renegotiate the dynastic union of 1603: the Jacobean endeavour to 'perfect' it, the Scottish push for a Covenanted union in the 1640s, the imposition of incorporating union in the 1650s by an English republican regime which grudgingly accepted that Scotland would not secede, fleeting negotiations in the late $1660 \mathrm{~s}$ and 1689, and the arguments which preceded the Union of 1707. All these debates, including the early eighteenth century ones, focused more on the type of union to be established than on whether any union should exist. In the 1690s the composite state was also a Britanno-Dutch one (though nobody called it that). Yet historiography on these topics has had little to say about councils and counsel. This chapter thus offers some suggestions as to what role, if any, was envisaged for British advisory mechanisms and what impact the lack of such plans had on the composite state. ${ }^{3}$ Which advisory institutions, if any, were thought of as operating in a British fashion, with mixed Anglo-Scottish membership: parliaments or privy councils? Would these replace individual kingdoms' councils with British ones, or would they provide an extra layer of governance in addition to separate English and Scottish ones, reflecting the way in which any British identity would have to be laid atop of continuing national, sub- and cross-national identities? Or, if British councils were not proposed, is this a sign that counsel rather than councils was seen as the most natural and effective lubricant between the British kingdoms?

\footnotetext{
3 'Britain' and 'British' will be used here for Anglo-Scottish relationships: as has been well established by other scholars, Ireland tended to be an afterthought in Anglo-Scottish negotiations, although the economic disadvantages of its subordinate status were increasingly noticed by late-seventeenth-century Scottish commentators.
} 
The lack of institutional mechanisms for joint government left a significant gap in the seventeenth-century British state system. Two factors contributed to this lacuna. One was the nature of the union. In theory the dynastic union was one which early modern writers would have termed a union aeque principaliter, in which each partner maintained its own laws, privileges, identity and status. Because it was not what contemporaries termed an 'accessory' (in our parlance, incorporating) union, ${ }^{4}$ it seemed appropriate officially to leave English and Scottish institutions to function separately under one monarch. Only plans for a confederal or federal union required mutual and joint councils to be considered, because these necessitated engagement with what Roger Mason has termed the 'East Lothian Question': how a union of unequal partners might work. ${ }^{5}$ Such plans were mooted in the 1640s, but after 1660 became tainted by their association with the Civil Wars of the 1640s and Scottish Covenanting radicalism. The second factor is that emphasised by this volume: contemporaries thought instinctively in terms of counsel rather than councils. The British state system could, however, have operated without a British council had counsel worked effectively to fill the gap. It was the lack of a well-functioning system of British counsel combined with a union aeque principaliter in name only, which was the ultimate flaw. A

${ }^{4}$ J. H. Elliott, ‘A Europe of Composite Monarchies', Past \& Present, 137 (1992), 48-71; R. A. Mason, 'Debating Britain in Seventeenth-Century Scotland: Multiple Monarchy and Scottish Sovereignty', Journal of Scottish Historical Studies, 35 (2015), 1-24.

${ }^{5}$ R. A. Mason, 'Posing the East Lothian Question', History Scotland, 8 (2008), 40-8. This article will use con/federal as a descriptor for non-incorporating union, as there was no distinction between confederal and federal unions until the late eighteenth century: J. Robertson, 'The Conceptual Framework of Anglo-Scottish Union', in J. Arrieta and J. H. Elliott (eds), Forms of Union: The British and Spanish Monarchies in the Seventeenth and Eighteenth Centuries (Donostia, Esuko Ikaskuntza, 2009), p. 136. 
union whose members lacked parity of status and esteem witnessed growing tension over the apparent royal preference for English episcopalianism, English trade and English ministers. The perceived sidelining of Scottish voices and Scottish grievances reflected the apparent malfunctioning of counsel under an absentee ruler. ${ }^{6}$ The neglect of British counsel inhibited other British tensions being reconciled and the lack of any British council left subjects with no institutional recourse. Arguments over religion and trade were impossible to solve because neither counsel nor councils operated as an effective geographical or political link to achieve consensus and cooperation. The absence of British counsel was thus a major contributing factor to the British problem.

The implications of J. H. Elliott's remark that even a 'nominal' council of state which would act as an 'instrument for final policy decision and coordination' was 'something notably absent' in the British case have never yet been teased out. ${ }^{7}$ Given this volume's attention to both English and Scottish counsel, this seems the appropriate place to undertake such an exercise. Elliott may have been correct that neither of the first two Stuart kings created 'a council for all Britain', ${ }^{8}$ but other commentators on union sometimes did propose such an institution. Tracing these suggestions across the century, this chapter provides some concluding comments drawing together Anglo-Scottish politics and the issue of counsel. After surveying the plans (or lack thereof) for British councils in the various phases when union was debated, it turns to an epiloguic discussion of the changing role of counsel in the

\footnotetext{
${ }^{6}$ Given constraints of space, this conclusion will focus on the perception of Scottish voices going unheard and the lack of formal requirements for joint membership of councils: further research, and prosopographical analysis, might well reveal more British counsel actually taking place than appears on the surface.

${ }^{7}$ Elliott, 'Composite Monarchies', 55.

${ }^{8}$ Elliott, 'Composite Monarchies', 56.
} 
final two decades before the Treaty of Union of 1707 through examining the relatively neglected debate over 'evil counsel' in both England and Scotland after the Revolution of 1688. In this period, England's novel experience of absentee monarchy generated angry exchanges about foreign counsels and calls for parliament to debar aliens from being privy councillors. The events of the late 1690s also brought the conciliar flaws in Britain to the forefront of Scottish attention, and the ensuing debate reflected a serious and close engagement with the history of the seventeenth-century kingdoms which produced a rich variety of proposals for rethinking counsel embedded in discussions of possible forms of union. Thus both England's and Scotland's experience of being part of a Dutch composite state deeply engaged in major warfare was a new context in which old and new ways of discussing counsel fused. The era from 1688 to 1707 was a liminal period in which older suggestions for parliamentary appointment of councils revived, but were proposed and defended using new political languages of fiduciary monarchy, parliamentary sovereignty and interest. Once the possibility of England and Scotland having opposing interests had been recognised, counsel was no longer required to achieve some imagined unitary common good. The incorporating union of the parliaments in 1707 was a way of avoiding, rather than solving, the vexed question of how counsel would hold together any alternative nonaccessory union under a single dynastic head.

Most writers in the Jacobean union debate offered minimal comments on counsel. There were passing references to European examples, such as John Doddridge's account of how the Spanish-Portuguese union had resulted in a council of Portugal whose advice the now absent monarch should take. Doddridge advocated a common parliament, stated the detailed 
mechanisms of this would be contentious and unhelpfully offered no suggestions for how to organise it. ${ }^{9}$ Henry Savile allowed for joint participation in service at court and in the army, but insisted that other officers of state be natives of their kingdom. Savile envisaged two separate councils, yet suggested that the king choose 'one or two of the most considerate, in whom he putteth most confidence' to sit on their neighbour nation's council. ${ }^{10}$

Only one writer, David Hume of Godscroft, offered a plan for a joint council. Hume's willingness to engage with institutional mechanisms is striking, for he had a soundly Buchananite view of aristocratic counsel and his discussion of religion and the union included a classical humanist paean to the virtuous and manly practice of frank speech outwith any institutional setting. ${ }^{11}$ Yet here was a humanist who thought about councils as well as counsel. 'There shall be one supreme council of Britannia', Hume's chapter on 'Concilia' declared, twice the size of the English privy council, with equal numbers of Scots and Englishmen to advise the king on his own affairs and on those of the kingdom (and, it later transpires, solve religious conflicts as well). This body would oversee a system of regional councils, supplementing those in the North and in the Duchy of Lancaster with ones in London, Edinburgh and Aberdeen. 'Cumbria shall be governed from Edinburgh, Annandale from York.' One fifth of the members of each of these councils would be

${ }^{9}$ Jacobean Union: Six Tracts, pp. 156, 146; for lack of attention to councils see also B. Galloway, The Union of England and Scotland, 1603-1608 (Edinburgh, John Donald, 1986), pp. $41-2$.

${ }^{10}$ Jacobean Union: Six Tracts, pp. 232-3.

${ }^{11}$ The British Union: A Critical Edition and Translation of David Hume of Godscroft's De Unione Insulae Britannicae, ed. P. J. McGinnis and A. H. Williamson (Aldershot, Ashgate, 2002), pp. 226-7; he adds a Protestant gloss to this. On Buchanan see Rose's introduction to this volume, p. 00; on Hume, see section I of Mason's chapter in this volume. 
representatives of the previously foreign nation. Hume thought that these bodies would foster Anglo-Scottish contact and provide examples of British unity. Yet his underlying rationale remained baronial virtue: the majority of the council should be nobles, the hands and sinews of monarchy, men inspired by their ancestors' virtue (Buchanan again). This was further supplemented by climatological stereotyping: if the Scottish climate made its people more excitable, the English one its men more subtle, then 'the council, taken as a whole, may well be wiser and better than the individuals who make it up'. ${ }^{12}$ This British council would exist in tandem with a British parliament sitting at York, modelled on the superior English parliament. ${ }^{13}$

No institutional British council emerged from the Jacobean union debates, although five naturalised Scots would sit on the Jacobean English privy council. ${ }^{14}$ By the late 1630s, deep discontent with the place of Scotland within the union, and the lack of routes by which Scottish grievances and counsel could reach the ears of Charles I, resulted in open rebellion. As royal power crumbled first in one, then in all three kingdoms, informal systems of advice which rested on access and intimacy could not provide even the figleaf of British consultation. As the thin veneer of British counsel cracked, institutional councils were again suggested to fill the gap.

The alliance forged between the Scottish Covenanters and the English opponents of Charles I offered an opportunity to renegotiate a problematic union. It was the Covenanters who took the initiative in re-envisaging a con/federal union. This union would be godly, it

\footnotetext{
${ }^{12}$ Hume, British Union, pp. 210-11, 224-5, ch. 5, pp. 176-83.

${ }^{13}$ Hume, British Union, ch. 6. The title of this chapter in the British Library manuscript is ambiguous: 'Concilium, sive regni comitia', but the two bodies are clearly separate: pp. 2845.

${ }^{14}$ Galloway, Union, pp. 17-18.
} 
would be royal - allegiance to the Stuarts was constantly reiterated - and it would be constitutional - the king's powers were to be limited. It captured the paradoxes long inherent in Scottish attitudes to their king: a proud allegiance to the Stuarts which resented any external interference in their realm, coupled with insistence that royal power be limited by good advice, and perhaps by external control of the king's advisers. The union would remain dynastic, but its constitutionalist edge manifested itself in a clearer institutional system for resolving tensions between the kingdoms. The Covenanting vision was first expressed in the Instructions the Scottish Committee of Estates gave its commissioners negotiating with the English parliament in early November 1640. The first and fourth clauses capture the above paradox, stating Scotland was dependent on none but her king; and that the Scottish estates could only be prorogued with their own assent, but with or without royal assent. The longest, the nineteenth, sketched the principles of union: free trade, a common confession, no war to be fought without the assent of both parliaments. As has been noted by previous scholars, parliaments in both nations were to sit every two to three years 'in which wrongs done by either nation to [the] other are to be tried, and Commissioners appointed to treat about them', while between parliaments 'Commissioners of both nations should be chosen, to be entitled Conservatores pacis, who may have power jointly to try and remedy any differences and wrongs that may arise'. ${ }^{15}$ What has been less remarked is that these Commissioners were not only to adjudicate differences between monarch and subjects, but also to try 'those who have

${ }^{15}$ Calendar of State Papers Domestic, Sept. 1640-May 1641, ed. W. D. Hamilton (London, Longman, 1882; henceforth, CSPD), pp. 244-6; see D. Stevenson, 'The Early Covenanters and the Federal Union of Britain', in R. A. Mason (ed.), Scotland and England, 1286-1815 (Edinburgh, John Donald, 1987); J. Morrill, 'Three Kingdoms and One Commonwealth? The Enigma of Mid-Seventeenth-Century Britain and Ireland', in A. Grant and K. J. Stringer (eds), Uniting the Kingdom? The Making of British History (London, Routledge, 1995). 
given bad counsel to either, have been incendiaries, or encroached on the King's power, or liberties of religion and the country'. This could refer to four groups or one. That the bad counsellors encompassed the following three groups is suggested by the final clause in the nineteenth instruction, which attributed all evils to the 'innovations brought in of late' which would not have grown so high if the Council and Session had not given way to them. For preventing the like inconveniences, you are to desire that the supreme judicatories of Council and Session may be reduced, as far as may stand with our religion, to their first institution and practice before King James's going to England. ${ }^{16}$

Noteworthy here is the condemnation of the dynastic union of 1603 as much as the ill governance of Charles I. While the solution was partly an institutional one of providing arenas for reconciliation of English and Scottish differences through an extra layer of consultation added onto previous mechanisms for governance, access (and its consequent chances for informal counsel) was simultaneously sought. Scots were to 'have service about the King and Prince, some in chief places'. Counsel must supplement councils.

This Scottish Covenanting view of union was reiterated throughout the 1640s. The Solemn League and Covenant announced the need to maintain 'a firm peace and union' and to punish malefactors who divided the kingdoms from each other. ${ }^{17}$ It seems that it was

${ }^{16}$ CSPD, Sept. 1640-May 1641, p. 246; see also the English House of Commons' instructions to its committee in Scotland in November 1641, which blames evil counsellors for all the ills of the three kingdoms: S. R. Gardiner, Constitutional Documents of the Puritan Revolution, 1625-1660 (Oxford, Clarendon, 3rd edn, 1906), pp. 199-201.

${ }^{17}$ Gardiner, Constitutional Documents, pp. 269-70. Aggrieved Covenanters tried to prosecute Cromwell under this clause: D. Stevenson, 'Cromwell, Scotland and Ireland', in J. Morrill (ed.), Oliver Cromwell and the English Revolution (Harlow, Longman, 1990), p. 152. 
impossible to admit that each might have separate interests. Evil counsel remained a necessary rhetorical device to explain away any clash between them. While the Covenanting vision persisted, which English individuals seemed likeliest to respond to it changed. ${ }^{18}$ From 1640 to circa 1647 it was the English parliament; thereafter it was the king. A 'firm union' was urged in the Engagement between some Covenanters and Charles I in 1647. Charles promised that if the endeavour to make the kingdoms 'one' through a 'complete union' failed, there would at least be free trade and common privileges. The additional articles of 26 December 1647 are the most telling with regard to counsel. These expanded the general promise of a visit to Scotland by Charles or his son to a commitment that either 'shall reside in Scotland frequently as their occasions can permit, whereby their subjects of that kingdom may be known unto them'. Simultaneous commitment to both British councils and counsel is also evidenced: a 'considerable and competent number' (originally a third) of each kingdom's council was to be made up of representatives of the other nation, and Scots were to have a proportionate number (set by the king at a third) of places serving the king, queen, prince of Wales and royal family. ${ }^{19}$ Here there are joint councils, rather than an extra layer of parliamentary-nominated conservators of the peace, but presumably the joint representation is envisaged as allowing the king to hear (and heed) both his kingdoms. The legislation of 1641 which provided for the Scottish parliament to nominate the privy council would have remained in force; interestingly, the appointments which parliament and Charles had made in 1641 included English supernumeraries. ${ }^{20}$ This tilt back towards the monarchical rather than parliamentary elements of Covenanting con/federal union arose in large part from exasperation with the lack of English interest in union, with horror at the rise of

\footnotetext{
${ }^{18}$ Stevenson, 'Early Covenanters', pp. 173-6.

${ }^{19}$ Gardiner, Constitutional Documents, pp. 350, 351, 353.

${ }^{20} \operatorname{RPS}, 1641 / 8 / 55,1641 / 8 / 161$.
} 
Independency and sectarianism as English Presbyterianism foundered, and dislike of the antimonarchical tendencies of the New Model Army. In short, the English appeared to be violating all the key principles of the League and Covenant solemnly contracted with Scotland and jointly avowed before God.

Ironically, the forging of the Engagement led to the abolition, in January 1648, of a rare active British conciliar body: the Committee of Both Kingdoms. Created in 1644 'for the best advantage of the three kingdoms [like the Solemn League and Covenant, this AngloScottish body happily spoke for an unconsulted Ireland] and the keeping a good intelligence between ... their forces, committees, and counsels', the Committee still worked on behalf of 'both' the 'two nations'. ${ }^{21}$ Although John Adamson has demonstrated how the Solemn League forced parliament to confront the question of how to replace the privy council, the Committee's parallels with medieval plans for aristocratic councils, and the factional rivalries between Essex and more radical warmongers which played out in it, historians have paid limited attention to the Committee and its workings would merit further study. ${ }^{22}$ It does not seem to have provided a model for future British councils. No equivalent body is explicitly mentioned in the peace proposals offered to Charles at Uxbridge in 1644 and Newcastle in 1646. The one hint in the former (dropped in the latter) is that the joint advice of both kingdoms was to be taken regarding Ireland. ${ }^{23}$ Otherwise the proposals returned to the scheme of 1640. Each kingdom's army and navy were to be managed by commissioners which both kingdoms might 'confide in' (trust), though chosen by their own parliaments. Up

${ }^{21}$ Gardiner, Constitutional Documents, pp. 271-4.

${ }^{22}$ J. S. A. Adamson, 'The Triumph of Oligarchy: The Management of War and the Committee of Both Kingdoms, 1644-1645', in C. Kyle (ed.), Parliament at Work (Woodbridge, Boydell, 2002).

${ }^{23}$ Gardiner, Constitutional Documents, pp. 278, 304. 
to a third of these commissioners were to be sent to the other kingdom to vote on their questions, and the conservatores pacis were to be established. This was a return to the scheme of mutual representation on each other's councils, alongside the commissioners - i.e. the British joint body would reconcile ad hoc tensions rather than providing quotidian British governance. The rest of the proposals blended parallel limitations on the king to be enforced separately in both kingdoms (parliamentary assent to appointments of officers of state and to sending forces into the other kingdom) with occasional reference to joint assent (for the religious settlement, employing any members of the royalist Oxford parliament, the education and marriage of the royal children, war and peace). No mechanism for how this joint assent was to be worked out was described, and the tendency to outline an English settlement followed by 'and so for Scotland' may signal lack of coordination of the proposals. ${ }^{24}$ The English parliamentarians were uncommitted, and the New Model Army still less interested, in fostering union. The attempt to shake off Scotland's British pretensions in 1649, when a republic was declared in and for England and Ireland only, was more representative of English attitudes to Scotland than Cromwell's conquest: indifference frequently trumped imperialism. It was Scotland's insistent declaration of Charles II as king of all three kingdoms which forced England's hand.

This explains why the incorporating union of the 1650s never generated British councils, and why a British parliament was slow to emerge. Since conquest and incorporation were 'very much a second best' in English eyes, the chance for a 'real Britain' with 'genuinely multinational institutions' was missed. ${ }^{25}$ Yet if English indifference

${ }^{24}$ Gardiner, Constitutional Documents, pp. 275-86, 290-306.

25 J. Morrill, 'The English, the Scots, and the Dilemmas of Union, 1638-1654', in T. C. Smout (ed.), Anglo-Scottish Relations from 1603 to 1900, Proceedings of the British Academy, 127 (2005), 57-74, at 64; A. H. Williamson, 'Union with England Traditional, 
frequently trumped imperialism, when indifference lapsed, imperial assertiveness took its place. The rapidity of Cromwell's victories in Scotland - which was, of course, the first time an English army had conquered its auld enemy - was striking. So too is the draft act of September 1651, 'Asserting the Title of England to Scotland'. ${ }^{26}$ The Tender of Union and the apparent consultation with shire and burgh deputies about it between January 1652 and April 1653, was thinly disguised coercion. The deputies were to 'receive ... commands'. Their elected representatives had to assent to union in order to take up their positions. On 13 of the 35 occasions when the English parliament's committee met to debate the union, no Scottish deputies were present and, although the union bill was read out to them, they were not allowed a written copy. ${ }^{27}$ Officially, Scotland was involved in the process; in reality, consent was being extorted and only the fictive shadow of counsel - the 'solemn farce' ${ }^{28}$ of consultation - existed. The union bill was lost when Cromwell dissolved the Rump, replaced by the Protectoral Ordinance which proclaimed a 'happy union' of the English and Scottish peoples under 'one Commonwealth' and 'one Government'. Protectoral government resulted

Union with England Radical: Sir James Hope and the Mid-Seventeenth-Century British State', English Historical Review, 110 (1995), 303-22, at 322.

${ }^{26}$ Journals of the House of Commons, VII, 22; The Cromwellian Union, ed. C. Sanford Terry (Edinburgh, Edinburgh University Press, 1902), p. xvii; F. D. Dow, Cromwellian Scotland, 1651-1660 (Edinburgh, John Donald, 1979), p. 30; see ch. 1 on the military campaign.

${ }^{27}$ Dow, Cromwellian Scotland, ch. 2. Williamson notes the reluctance even of unionists to swear allegiance to the 'English' republic: 'Union with England', 314-15.

${ }^{28}$ Stevenson, 'Cromwell, Scotland and Ireland', p. 165. 
in a British and Irish parliament, for thirty Scottish and thirty Irish MPs sat in Cromwell's parliaments. Many of Scotland's MPs were Englishmen. ${ }^{29}$

Under Cromwell, therefore, joint Anglo-Scottish government existed in parliament. But in the periods when parliament did not sit, it was institutionally non-existent, for none of the multiple constitutional regimes of the Interregnum ever systematically organised British conciliarism. However significant or not the Protectoral council was, ${ }^{30}$ it was not a British institution. Only one Scotsman, Sir James Hope, ever sat in Cromwell's Council of State and that briefly. ${ }^{31}$ No mechanism was suggested to resolve Anglo-Scottish tensions. Declaring an incorporating union thus avoided rather than faced up to the management of multiple states. But did the lack of a formal British council mean than British counsel did not take place? One opportunity for it was in the mixed government implemented in Scotland. High Sheriffdoms and commissions of the peace were held jointly by Scots and English officers; the Commission for the Administration of Justice was split between four Englishmen and three Scots (the latter on half the salary of the former). Previously this has been interpreted as imposing English dominance on Scotland, and to a large degree that was the intent behind it: driven by the desire for military and political security. Yet counsel must

${ }^{29}$ Gardiner, Constitutional Documents, pp. 418-22. Nine of the 22 returned in the First Protectorate Parliament were English; 16 of the 30 in the Second: P. Little and D. L. Smith, Parliaments and Politics during the Cromwellian Protectorate (Cambridge, Cambridge University Press, 2007), p. 268 (see ch. 12 on the Scottish MPs); Dow, Cromwellian Scotland, pp. 185-6.

${ }^{30}$ P. Gaunt, “"The Single Person's Confidants and Dependants”?: Oliver Cromwell and his Protectoral Councillors', Historical Journal, 32 (1989), 537-60; B. Worden, 'Cromwell and his Councillors', in his God's Instruments (Oxford, Oxford University Press, 2012).

${ }^{31}$ Williamson, 'Union with England', 317-20. 
have gone on, at least at a minimal level of exchanging information, for English army officers simply lacked the expertise in Scottish law to govern the country. Furthermore, between September 1655 and August 1656 Lord Broghill's headship of the Scottish government embodied British rule: the son of the earl of Cork was chosen by an Englishman to head the Scottish council. Broghill's commitment to civilian government and to securing consent for the regime in a pan-British context led him to encourage broader consultation within Scotland in the mid-1650s. His kinship ties and broader network fostered links with Scottish elites and churchmen before his arrival in Scotland. These offered opportunities for Scottish counsel to supplement Broghill's formal council. ${ }^{32}$ It is possible that further work on 1650s Scotland will reveal informal advice to Broghill, Monck or Cromwell filling the gaps left by the lack of a formal British council. At present we have only tantalising hints, such as the meeting between the Hope family and English army officers in 1651. Was Sir James Hope's vision of meeting Cromwell and 'expostulat[ing] much' with him about Scotland merely a dream? ${ }^{33}$

Therefore, just as military power could force through republican government and religious pluralism in the 1650s but not sustain it, so too could it impose but not perpetuate an incorporating union. Although the Conventions of Shires and Burghs which met in February 1660 urged Monck to press for 'ane way ... for vniting the natiouns', ${ }^{34}$ the return of the

${ }^{32}$ Dow, Cromwellian Scotland, ch. 8 and pp. 162-4; Stevenson, 'Cromwell, Scotland and Ireland', p. 170, p. 172 dates this from the last phase of Lilburne's tenure as commander-inchief. P. Little, Lord Broghill and the Cromwellian Union with Ireland and Scotland (Woodbridge, Boydell, 2004), ch. 4, esp. pp. 93-100; and his essay 'The Irish and Scottish Councils and the Dislocation of the Protectoral Union', in P. Little (ed.), The Cromwellian Protectorate (Woodbridge, Boydell, 2007).

${ }^{33}$ Williamson, 'Union with England', 313, 315.

${ }^{34}$ Terry, Cromwellian Union, p. xcvi. 
Stuarts restored separate parliaments and separate councils. Tantalising hints of a British and Irish advisory group exist in the London-based committee of Lauderdale, Clarendon, Ormonde, Monck and Manchester operating in the early 1660s, but this body is obscure. Although there were negotiations in the late 1660s and union was fleetingly mooted in early 1689 , neither occasion involved discussion of joint privy councils. Restoration monarchs might have played their kingdoms off against each other, but they made sure to govern them separately.

\section{II}

The Revolution of 1688 brought to Britain's shores a new type of ruler: one experienced in governing a composite state. The Dutch stadtholder not only temporarily broadened the dynastic union across the North Sea, but also drew his British and Irish kingdoms into the major Continental warfare which necessitated wholesale military and financial reorganisation. Yet no special formal conciliar institutions were created to govern the AngloIrish-Scottish-Dutch union. Had any been invented, they might not have been welcomed. To many at the time it already seemed as if a Dutch train of Williamite servants had arrived in their supposed liberator's wake. A pamphlet of 1690 spoke of a Dutch cabal and Dutch favourites who encouraged William down arbitrary paths, leading him to dissolve his great council of parliament and to scorn his privy council. ${ }^{35}$ A speech to parliament in 1702 sketched a history of foreign evil councillors from King Stephen to Edward II. Since kings, 'being cloathed with frail Nature', tended to listen to 'their Favourites and Flatterers', it was vital that 'the great Council of the Nation should interpose for the Interest of the King and

${ }^{35}$ The Dear Bargain, or a True Representation of the State of the English Nation under the Dutch (n.p., 1690), pp. 22-3. 
People'. This traditional denunciation of the tendency of merely mortal monarchs to listen to bad advice was combined with a novel post-revolutionary gloss of the king breaking the original contract by granting his patrimony to his favourites. ${ }^{36}$ And, a month after parliament addressed the king to remove foreign advisers from the privy council, John Tutchin's poetic denunciation of alien evil counsellors, The Foreigners, sparked a series of responses culminating in Daniel Defoe's classic The True-Born Englishman. ${ }^{37}$

Perhaps significantly, these complaints - which focused on William's longstanding adviser Hans Willem Bentinck, earl of Portland - echoed in comments by aggrieved royal servants as well as in the public sphere of printed polemic. These reflected age-old concerns about being able to access the monarch in order to give him counsel as well as worries about who sat in the privy council. Halifax bemoaned William's preference for 'single conversations' over councils, when 'a prince must have both'. An anonymous pamphleteer commented on the king being 'conversant not only Hours, but whole Days together, with his Bentincks and Capels' while Scottish advisers waited months to meet him. Such worries were especially intense in the aftermath of Mary II's death, as William allowed Portland in but shut out his privy councillors. ${ }^{38}$

${ }^{36}$ [Robert Price], Gloria Cambriae: Or, the Speech of a Bold Britain in Parliament, in A Collection of Scarce and Valuable Tracts, vol. III (London, 1748), pp. 101-2. Page 100 offers a tantalising hint of a sense of a specifically Welsh original contract.

${ }^{37}$ John Tutchin, The Foreigners (London, 1700), esp. pp. 4-8; Anon., The Apostates (London, 1701), esp. pp. 5, 9-10. For further polemic see D. Onnekink, The Anglo-Dutch Favourite: The Career of Hans Willem Bentinck, 1st Earl of Portland (Aldershot, Ashgate, 2007), ch. 7.

${ }^{38}$ For such complaints see D. Onnekink, "'Dutch Counsels": The Foreign Entourage of William III', Dutch Crossing, 29 (2005), 5-29, at 8, 13-14, 7; Onnekink, Anglo-Dutch 
Yet, as David Onnekink has shown, complaints about Dutch counsels were inaccurate, thinly-veiled attacks on royal policy from Jacobites (such as Nathaniel Johnson, the author of the 1690 pamphlet) and disaffected whigs and tories. William drew on an international - not purely Dutch - cadre of experienced military commanders, as indeed he had to, given the paucity of talent and dubious loyalty on offer to him from Britain. ${ }^{39}$ Complaints of 'Dutch bishops, Dutch presbyters, and Dutch commanders ... [soon] Dutch lords, Dutch commons, and Dutch every thing' were wildly inaccurate. There were no Dutch placemen in the Commons and few naturalised foreigners in the House of Lords. It was William, not his advisers, who set the sometimes authoritarian tone of his government. ${ }^{40}$ As some of the respondents to Tutchin recognised, evil counsel was just a way of attacking the king: 'Envy's not contented to Prophane / Agrippa's Friend, but dares his Master's Reign, / Under the Subject, it reviles the Prince, / And calls the truest Service an Offence'. The author of these lines, John Dennis, was, however, unusual in explicitly defending William's prerogative to choose his councillors. If England accepted Portland's martial service, why

Favourite, pp. 102, 109, 163. It is possible that Portland was merely a filter to allow William to block those he did not wish to see: D. Onnekink, "“Mynheer Benting now rules over us": The 1st Earl of Portland and the Re-emergence of the English Favourite, 1689-99', English Historical Review, 121 (2006), 693-713, at 700.

${ }^{39}$ Onnekink, Anglo-Dutch Favourite; Onnekink, 'Mynheer Benting'; Onnekink, 'Dutch Counsels'.

${ }^{40}$ Onnekink, 'Dutch Counsels', 10. For Portland's limited influence, see Onnekink, AngloDutch Favourite, pp. 36, 103, 107, 129ff. 
not his counsel $?^{41}$ Portland was a counsellor, but not an overweening minister-favourite: a 'friend' as well as a 'minister' according to Burnet; 'ye man ye Prince most confides in, \& to who he unbosomes his private thoughts, his feares \& his pleasures' according to an earlier Dutch writer. ${ }^{42}$ He was, nevertheless, a liminal figure. His authority and status derived from his intimacy and regular contact with the king and his household offices. Yet his administrative skills proved useful in organising war at a point when the state's sphere of activity was expanding faster than its infrastructure. ${ }^{43}$ Most significantly here, Portland provided an informal link between William's multiple territories. He held positions in the United Provinces, as a Presbyterian he was more acceptable to William's Scottish subjects than any English episcopalian would have been and his reports from the Irish campaign provided the basis for propagandist newsbooks. ${ }^{44}$ It was, perhaps, no coincidence that William's authority in Scotland decreased as Portland's prominence waned. 'I had always full time allowed by him for giving him information' wrote Secretary Ogilvy in $1697 .{ }^{45}$ When the informal counsel which had lubricated the composite state declined, there was - as ever - no formal council to step into the breach. This left a crucial gap as conflict between England and Scotland grew in the late 1690s.

${ }^{41}$ John Dennis, The Reverse, 2nd edn (London, 1700), pp. 10-11, 6; Daniel Defoe, The TrueBorn Englishman and Other Writings, ed. P. N. Furbank and W. R. Owens (London, Penguin, 1997), lines 646, 648.

${ }^{42}$ Onnekink, Anglo-Dutch Favourite, p. 17.

${ }^{43}$ See esp. Onnekink, 'Mynheer Benting'.

${ }^{44}$ Onnekink, Anglo-Dutch Favourite, pp. 21, 68, 112, $116 \mathrm{ff}$.

${ }^{45}$ State Papers and Letters addressed to William Carstares, ed. J. McCormick (Edinburgh, 1774), p. 351. 
English dislike of William's favourites resulted in the clause in the Act of Settlement of 1701 which banned any born out of the dominions of England, Ireland and Scotland, even if naturalised, from sitting on the privy council. It revived earlier desires to contain counsel in accountable councils by ordering that all matters cognizable by the privy council be transacted there and all resolutions be signed by those who advised and consented to them. ${ }^{46}$ In Scotland, smouldering resentment at being excluded from access to the king erupted to an even greater extent in the late 1690s and early 1700s. Both the Scottish and English commentary on evil counsel complained of the nation's interest going unheeded, but to Scotland evil counsel seemed even more invidious because it involved both foreign ministers overriding Scottish interests and native governors betraying their country. The address against William's adjournment of parliament in 1701 bemoaned the evils of 'foreign influence, as well as ... the misrepresentations and pernicious counsels of unnatural countrymen'. ${ }^{47}$ The Scottish response was thus to return to earlier calls for reconstituting systems of council.

Nowhere was this more apparent than in the pamphlet debate over the failed Darien scheme. Intended by its creator as a joint Anglo-Scottish colony, the scheme became a purely Scottish venture when William prevented English involvement. The king's inhibiting financial support, his refusal to publicly authorise the venture and his blocking of English aid to the beleaguered Scottish colonists, seemed to symbolise all that was flawed about Williamite governance of Scotland. While Darien's significance in the union debates has stimulated historiographical attention to Scotland's economy, the initial debate focused on the impoverishment of Scottish sovereignty and the lack of means by which to inform the king

${ }^{46} 12 \& 13 \mathrm{Wm}$ III, c. 2 . The wording probably prevented the Alien Act of 1705 (3 \& 4 Anne, c. 6) which defined Scotsmen as aliens automatically excluding Scottish councillors. ${ }^{47}$ State Papers ... addressed to Carstares, p. 681. 
about Scottish concerns. ${ }^{48}$ Like the English debate over Portland, the Scottish argument about evil councillors employed both old and new political languages. The rise of the language of 'interest' made it easier than it had been earlier in the seventeenth century to depict English and Scottish interests as inherently opposed, and therefore as requiring constitutional constraints on the monarch to ensure he governed both fairly. When it came to specifying limitations, however, old schemes were revived.

\section{III}

The Scottish parliament's address about the unnatural betrayal of Scotland's interests by William's councillors echoed in the public printed literature on the Darien affair. An Enquiry into the Causes of the Miscarriage of the Scots Colony at Darien bemoaned the loss of the 'able and faithful' Secretary James Johnston to a faction who encouraged the king to neglect his northern kingdom. The author insisted that William's comment that he had been 'ill served' in Scotland could not have been made without advice. Givers of such counsel were 'nothing but mean-spirited Flatterers, or such as temporize with Courts, because of their own private Advantage'. Their counsel dishonoured their king: to say William was imprisoned by such men was no insult, but rather the 'best Apology' that could be made for him, since the alternative was to admit that he was Scotland's enemy. Ominously, the tract invoked not just the hanging of James III's favourites at Lauder Bridge in 1482 but also that king's deposition in 1488. Kings who did not remove their evil counsellors could be 'voted to be lawfully

\footnotetext{
${ }^{48}$ The best recent account of Darien is D. Watt, The Price of Scotland: Darien, Union and the
} Wealth of Nations (Edinburgh, Luath, 2007). 
slain'. ${ }^{49}$ The Enquiry's claims echo in Scotland's Grievances relating to Darien, both probably by George Ridpath. The latter pamphlet's title page displayed a quote (out of Buchanan's History of Scotland) from William Wallace urging Robert Bruce to die to save his country's freedom for, Ridpath explained, Darien was the greatest betrayal of Scotland since Balliol's kingship. It revealed not simply the contrivances of the English parliament against Scotland, but also the more insidious connivance of a party of Scottish counsellors. Such men - especially the Secretary Seafield - were chargeable with the blood of dead settlers and ought to compensate the nation for its financial loss. Worse still, they blocked alternative routes of access to the king, so that William took decisions 'without consulting the Council of Scotland' ${ }^{50}$

Yet Ridpath's worry was less a marginalised privy council than a thwarted parliament. The king ought to have the advice of 'the Great Council of this Nation, in such a Weighty and General Concern'. It was ‘an essential part of our Constitution, for a King of Scots to Advise with his Parliament'. Fiduciary monarchy and the right of the Company of Scotland to petition the king were constitutional fundamentals embodied in the Claim of

${ }^{49}$ [George Ridpath], An Enquiry into the Causes of the Miscarriage of the Scots Colony at Darien (Glasgow, 1700), pp. 3, 9, 35-6; on James III, see Hawes's chapter in this volume. ${ }^{50}$ [George Ridpath], Scotland's Grievances relating to Darien ([Edinburgh?], 1700), pp. 1-6.

On Ridpath, see C. Jackson, 'Conceptions of Nationhood in the Anglo-Scottish Union Debates in 1707', in S. J. Brown and C. A. Whatley (eds), The Union of 1707: New Dimensions, Scottish Historical Review supplementary volume (Edinburgh, Edinburgh University Press, 2008). 
Right of $1689 .{ }^{51}$ William was a king constrained to act against his coronation oath in Scotland because forced to follow what the 'pernicious Counsellours' decided was in England's interest. 'They will not allow us to complain of our Kings when misled by Ill Council, or to say that by our Ancient Constitution, they were accountable to their Parliaments for Male-Administration ... yet they themselves fly in the Face of their Prince every day.' Perhaps William would do well to remember that the Claim allowed for royal forfeiture of the crown. ${ }^{52}$ There is a clear slippage here from the removal of evil counsellors to discarding the king himself. Anciently, Ridpath remarks, the heads of families in Scotland 'who were our real Nobility ... chose and gave laws to our Kings' and if monarchs acted against their advice, they deposed them. ${ }^{53}$ The Enquiry clearly felt that parliament had this power to enthrone or depose monarchs as it saw fit. To prorogue and adjourn parliament - as William kept doing - was a 'downright Violation of our Constitution', for it was a parliament which gave the king the best advice, not 'particular Persons'. Indeed, properly the king's council should be 'chosen and sworn in Parliament, and punishable by the States' ${ }^{54}$ Just as in the early 1640s, therefore, complaints about evil counsellors and the desire for them to be made accountable to parliament slid towards a theory of parliamentary sovereignty, now bolstered by the constitutional changes of 1689 .

Significantly, Ridpath's works combined the rhetoric of evil counsel with both a parliamentary spin and a history of malfunctioning British unions. The root of the problem

${ }^{51}$ [Ridpath], Scotland's Grievances, pp. 7, 12, 9. His emphasis on fiduciary government may have been a deliberate invocation of Lockean language to embarrass a member of the English Board of Trade for damaging Darien: see Jackson, 'Conceptions of Nationhood'.

${ }^{52}$ [Ridpath], Scotland's Grievances, p. 19.

${ }^{53}$ [Ridpath], Scotland's Grievances, p. 27.

${ }^{54}$ [Ridpath], Enquiry, pp. 110, 10-11. 
was, the Enquiry declared, the dynastic union of 1603, since which time Scotland had been left to the king's servants (and England to his 'minions'). Citing the English address to the king against foreign counsellors, the Grievances stated that, in Scotland too, 'none but Scotsmen ought to be consulted with in Scots Affairs'. Indeed, the only safeguard was to ensure that 'our Parliament should have the Chusing and Swearing of the Privy Councillors, as our Ancestors had; and a Power to call them to an Account, and punish them for MaleAdministration'. Only this - 'no more than our Birth-right' - would save Scotland from weak representatives influenced by 'Favourites, English Courtiers, or Prelates'. Similarly, all officers of state ought to be chosen in Scotland, by this new Scottish council (another echo of the early 1640s). ${ }^{55}$ Absentee monarchy lay at the heart of Scotland's woes. All Stuart monarchs had ruled in English interests and by English counsels since 1603, sacrificing in turn the kirk, Scottish liberties and Scottish trade. To ensure Scottish affairs were properly represented to William, a committee of parliament should report to him, with one or two of its members in constant attendance. By contrast, the Enquiry thought that the only solution was to create a committee made up of representatives from both parliaments to resolve disputes like Darien. ${ }^{56}$ Thus while Ridpath first advised a clear separation of English and Scottish counsels, he soon came to advocate a body to reconcile and manage relations between the two.

William's counsellors in Scotland and London shared some of these concerns. So too did Anne's: a joint English-Scottish council was mooted in $1704 .^{57}$ The difficulties which absentee monarchy posed for counsel are captured in a letter from one of those advisers, the duke of Queensberry, to William, in which the Scottish noble repeatedly states that speaking

\footnotetext{
55 [Ridpath], Enquiry, p. 41; [Ridpath], Scotland's Grievances, pp. 32-3.

${ }^{56}$ [Ridpath], Scotland's Grievances, pp. 31, 45; [Ridpath], Enquiry, p. 16.

${ }^{57}$ See Rose's introductory essay in this volume, pp. 00, 00.
} 
directly to the monarch would allow him to say things 'of importance to his service, and not so proper to be written', for oral communication would allow him to 'make my thoughts more fully understood, than is possible for me at a distance'. ${ }^{58}$ While in 1696 Seafield was sanguine about flows of counsel, believing that the Scottish Secretary had 'readie access' to the king and that William declared him to be 'ane man he could doe bussiness with', by June 1700 he was annoyed that the king would not assent to parliament's address about Darien. William was not interested in advice about how to respond to the Scottish parliament, but only on how to make his decision public. ${ }^{59}$ Seafield and others repeatedly urged the king to reach a good understanding with parliament, offer aid to the Scottish colonists seized and held as prisoners of war by the Spanish, and - above all - to come to Scotland in person. Although William was perhaps correct not to call parliament while absent, this only added to the need for his presence. Various Scottish counsellors framed their advice to William relayed through his Scottish Presbyterian chaplain William Carstares - with different degrees of intensity. Seafield invoked duty and service, adding a careful endorsement of William's prerogative right to decide when parliament might be called. The Lord Advocate coupled his advice to attend, given twice in quick succession in one letter, with a plea to "pardon all this freedom'. Others were more threatening. Murray of Philiphaugh told Carstares that the king ought to take the 'repeated advice' to come, otherwise he would have to visit Scotland on 'another errand' ${ }^{60}$ Although the king did not come, he dispatched his trusted chaplain Carstares instead.

\footnotetext{
${ }^{58}$ State Papers ... addressed to Carstares, pp. 639-40.

${ }^{59}$ Seafield Correspondence from 1685 to 1708, ed. J. Grant (Edinburgh, Scottish History Society, 2nd ser., 3, 1912), pp. 190, 290.

${ }^{60}$ Seafield Correspondence, pp. 300ff; State Papers ... addressed to Carstares, pp. 555-7, $422,518,552,559,572,601,616,629,636,658,659$.
} 
The last years of William's government of Scotland thus saw escalating tension which was seen as deriving from absentee monarchy which lazily delegated Scottish affairs to servile placemen and crushed the chance of parliamentary counsel. The accession of a new monarch in 1702 might have offered a chance to rebuild Anglo-Scottish relationships. Yet Anne's failure to call new elections frustrated many, and governance by aristocratic faction seemed set to continue. The succession crisis provoked by the death of Anne's son in 1700 forced union to the forefront of English minds; the queen pressed for negotiations from the point of her accession. The various union schemes proposed between 1702 and 1707 necessarily involved rethinking British counsel.

The most famous example of opposition to incorporating union is that which came from Andrew Fletcher of Saltoun, who offered an alternative vision of a European confederal union of smaller states. ${ }^{61}$ Crucial here is Fletcher's urging of 'Limitations' on any successors to Anne which would have ensured good Scottish counsel reached royal ears. Similar themes echo in Ridpath's works, although Ridpath was more inclined than Fletcher to attribute evil counsel to Scottish as well as English ministers in London. Significantly, both men combined an older language of evil counsel and calls for parliamentary appointment of councillors with a strong sense of parliamentary advice and, in Fletcher's case, neoHarringtonian or neo-Machiavellian inflections.

Both Fletcher and Ridpath saw the absentee monarchy resulting from the union of 1603 as the root cause of their country's problems. In speeches to the Scottish parliament of 1703, during one of his rare visits to his native kingdom, Fletcher explained that absent monarchs 'cannot be rightly informed' about Scotland. Royal grants of places and pensions to Scottish advisers in exchange for expanding prerogative authority there had left Scotland as enslaved to English ministers as if it had been conquered:

${ }^{61}$ J. Robertson, 'Andrew Fletcher's Vision of Union', in Mason (ed.), Scotland and England. 
So that there is no way to free this country from a ruinous dependence upon the English court, unless by placing the power of conferring offices and pensions in the parliament, so long as we shall have the same king with England. The antient Kings of Scotland, and even those of France, had not the power of conferring the chief offices of state, though each of them had only one kingdom to govern, and that the difficulty we labour under, of two kingdoms which have different interests governed by the same king, did not occur ... so long as Scots-men must go to the English court to obtain offices of trust or profit in this kingdom, those offices will always be managed with regard to the court and interest of England, though to the betraying of the interest of this nation. ${ }^{62}$

Since monarchs had a natural tendency - fostered by 'mean and fawning priests' - towards absolutism, limitations were necessary to avoid the risk of tyranny. Yet Fletcher also presented limitations less as encroaching on royal power than as a way to free Scotland from subjugation to the English court and the concomitant evil counsel which was conquest by the back door. ${ }^{63}$ Fletcher's repeated invocation of 'interest' was paralleled in James Hodges's plea that a con/federal union would serve English and Scottish interests - 'the only sure Basis of all National Transactions' - better than an incorporating one. Hodges's tract variously discusses fiduciary government (although fee- not contract-based), the neo-Roman concept of liberty as independence from another's will, and Fletcherite suggestions about the enervating

\footnotetext{
${ }^{62}$ Andrew Fletcher, Political Works, ed. J. Robertson (Cambridge, Cambridge University Press, 1997), pp. 132-4, 143: his closing remarks that Scotland might have lost even the desire to be free have a clear Machiavellian edge: see Machiavelli's Discourses, book I, discourses 16-18.

${ }^{63}$ Fletcher, Political Works, pp. 135-6, 145-7.
} 
effects of luxury and 'an Effeminate Esteem of nothing, but ... Money'. His account, although less concerned than Fletcher's or Ridpath's with evil counsel, nevertheless opened by bemoaning the loss of Scots' 'general and ready access' to 'Inform' their kings since 1603, and their reliance on dubious ministerial agents at the English court. Since dynastic union, there had been no less than 42 invasive constitutional innovations. ${ }^{64}$

Ridpath too was clear about 1603 as the origins of the problem. His Historical Account of the Antient Rights and Power of the Parliament of Scotland, dedicated to that body in 1703, spoke of a hundred years of 'Arbitrary Princes and fawning Courtiers'. Edward I and Cromwell had invaded, but dynastic union had destroyed Scottish sovereignty and its parliamentary basis. Parliamentary union would be even worse. How could Scots even contemplate 'such a Union ... as would subject our Bodies and Souls to the Votes of a foreign Majority'? ${ }^{65}$ The dynastic union had gone wrong, he argued in 1706, because it had never been properly negotiated: instead English legislation had crushed Scottish trade. Since the two countries shared some, but not all, interests, they should maintain a common allegiance but 'separate Laws, Councils, Judicatures ... Representatives'. Unlike the 1640s, therefore, here was an open admission that the two countries had distinct interests. But stability could only come with a negotiated treaty listing reserved powers, else the 'distinct Powers and opposite Interests' of the two would only result in 'a temporary precarious

${ }^{64}$ James Hodges, The Rights and Interests of the Two British Monarchies (Edinburgh, 1703), pp. 14-15, sigs. A3v-[A4]r; he does not specify the innovations.

${ }^{65}$ [George Ridpath], An Historical Account of the Antient Rights and Power of the Parliament of Scotland ([Edinburgh], 1703), preface (qu. pp. v, ix). 
Confederacy'. ${ }^{66}$ Ridpath envisaged the two parliaments being able to veto legislation passed by each other on matters of common concern, but insisted that it was advisable to appoint 'a Committee ... out of both [parliaments] to meet yearly, some time before the Meeting of the Separate Parliaments, in order to prepare and adjust Overtures touching these Incorporated Concerns'. This would render full parliamentary incorporation superfluous - and indeed would avoid the difficulties inherent to such a body. ${ }^{67}$

Ridpath blended an older tradition of aristocratic conciliarism and councillors appointed by and accountable to parliaments with a post-revolutionary sense of contractual monarchy. The title page of his Historical Account again quoted Buchanan - this time the De Iure Regni on the need to remember that kings were flawed mortals in need of advice. The first chapter, on resisting a sovereign who invades the constitution, cited the 1488 legislation on James III's deposition for heeding 'perverst counsel' and Buchanan on the overthrow of Mary Queen of Scots. ${ }^{68}$ Ridpath's introductory account of the nature of government described examples of Old Testament monarchs adhering to the original contract and the Claim of Right. And his final chapter on parliament's power over the succession cited Tacitus on Caledonian chiefs electing kings who 'acted in everything by the Advice and Authority of the Phylarchi, or Primores populi'. Until the fifth-century king Fergus II these phylarchs' conciliar role continued. 'And never was any of our Princes happy that did not govern by their Advice. ${ }^{69}$ Importantly, phylarchs usually signified rulers constitutionally

${ }^{66}$ [George Ridpath], Essay upon the Union (London, 1706), pp. 9-11, 6-8. Reserved powers here naturally means the opposite of what it does in a modern context, where it refers to powers retained at UK level.

${ }^{67}$ [Ridpath], Essay, pp. 26-7.

${ }^{68}$ [Ridpath], Historical Account, t.p., pp. 6, 11-13.

${ }^{69}$ [Ridpath], Historical Account, pp. xxiv-xxvi, 144, 149. 
limited, not just morally constrained by counsel. This reflected another interesting combination, the grafting of contemporary concerns about placemen in parliament onto the assertion of a medieval Scottish tradition of annual parliaments and parliamentary limitations on councillors. If parliament's members were true representatives of the kingdom rather than placemen, their advice could not but properly make manifest the interest of the nation. ${ }^{70}$ Ridpath suggested that parliaments should choose confessors, tutors of the royal children and the secret and privy councils. These would be 'sworn in the Presence of the King and three Estates, to give him true and plain Counsel in all Matters that concerned his Majesty and the Realm'. ${ }^{71}$ His description of parliament's powers over jura majestatis attributed all or most of Bodin's marks of sovereignty to it. Indeed, the collapsing of parliamentary counsel into legislative sovereignty was overtly admitted in Ridpath's discussion of how, regarding pardons, parliament 'counsel the King, which is the same thing with making an Act'. ${ }^{72}$

Ridpath's blend (or mish-mash) of Scottish history, classical humanism, elective monarchy, Biblical examples, conciliarism and constitutionalism was a theoretically messy but polemically powerful intervention in the Union debates. Starting with evil counsel, he moved to parliamentary constraints on appointment of advisers, and ended with parliamentary sovereignty in a con/federal union. We see a similar move in Fletcher's works. Indeed, with regard to succession, one is tempted to say that in Fletcher's speeches - and to some degree in the Act of Security (1704) - we see an early-eighteenth-century exclusion crisis, and the monarchical republic of Queen Anne. ${ }^{73}$ If Anne died with the succession

\footnotetext{
${ }^{70}$ [Ridpath], Historical Account, pp. 26-31, 52, 39-41, 51, 66.

${ }^{71}$ [Ridpath], Historical Account, pp. 102-7, qu. p. 103.

72 [Ridpath], Historical Account, ch. 5, qu. p. 90.

${ }^{73}$ P. Collinson, 'The Elizabethan Exclusion Crisis and the Elizabethan Polity', Proceedings of the British Academy, 84 (1994), 51-92, referring to ideas that in the event of Elizabeth I's
} 
unsettled, Fletcher declared, then any parliament in session should 'take the administration of the government upon them', hold new elections to replace the placemen who would be excluded from membership, proclaim conditions on which a successor would be received and, if this was the same as England's new monarch, tender the Claim of Right and coronation oath to them along with a set of further limitations. These would institute annual parliaments, a militia, remove the royal veto, require parliament's assent to war and peace and ensure all voting in parliament and council be by ballot. All appointments to offices of state would be made by parliament and, further, between parliaments a committee of 31 members would be chosen who would 'under the king, have the administration of the government, be his council', with power to call parliament if necessary, but always accountable to the next meeting of that body. ${ }^{74}$ Such limitations were only to be enforced if a dynastic union continued. ${ }^{75}$ The Act of Security was less radical, empowering the parliament and privy council to continue the government during the temporary interregnum which would result on Anne's death without an agreed succession, and vaguely desiring that any successor shared with England would be subject to 'conditions' to secure Scottish honour and sovereignty, 'the freedom, frequency, and power of parliaments, the religion, liberty and death leaving as her likely successor an alien Scottish Catholic (Mary Stewart), there would be a temporary interregnum government by a council of estate or expanded privy council which would govern the country and adjudicate the succession, its powers being based on statutory authority. Such notions, mooted from the 1560s by William Cecil, were enacted in mitigated form in the 1585 Act for the Surety of the Queen's Person.

${ }^{74}$ Fletcher, Political Works, pp. 137-40.

${ }^{75}$ Fletcher, Political Works, p. 141; p. 143 cheekily suggests this would remove the burden of governing Scotland from the king. 
trade of the nation from English or any foreign influence', and any additional conditions the estates chose to add. ${ }^{76}$

Fletcher expressed confidence that members of parliament would advise for Scotland's benefit, for each member was 'obliged by the oath he has taken to give such advice as he thinks most expedient for the good of his country' to the best of his 'knowledge and conscience'. Indeed, he offered his limitations scheme 'in discharge of my conscience and the duty of my oath in parliament'. ${ }^{77}$ Thus Fletcher could easily employ typical claims to act as an adviser: conscience, duty and an oath. His masterly Account of a Conversation Concerning a Right Regulation of Governments (1704) portrayed him enacting these virtues of free speech which his fellow interlocutor Sir Edward Seymour blindly rejects as to 'declaim' and 'cant'. Being a Revolution tory, Seymour cannot even recognise free speech and good counsel. ${ }^{78}$ Again Fletcher urges his limitations scheme as a way to avoid the dangers of an incorporating union, namely of more Scots travelling to London and being infected by the moral - and thus political - degeneracy of a large trade-based metropolis, alongside his own alternative European confederation of leagues of cities governed by councils. Seymour rejects this plan on the old monarchist grounds that conciliar government is always hopelessly divided. Fletcher's depiction of Seymour's dismissal of limitations as utopian ${ }^{79}$ reflects a broader Scottish sense that England simply failed to treat alternatives to incorporating union seriously. Mar made the same complaint to Carstares in March 1706:

\footnotetext{
${ }^{76} \operatorname{RPS}, 1704 / 7 / 68$.

${ }^{77}$ Fletcher, Political Works, pp. 158-9.

${ }^{78}$ Fletcher, Political Works, pp. 182, 185.

${ }^{79}$ Fletcher, Political Works, pp. 202ff, 208, 181.
} 
'they think all the notions about foederal unions and forms a mere jest and chimera' ${ }^{80}$ No such alternative made it formally onto the Anglo-Scottish negotiating table.

IV

As David Hayton has argued, the apparent flourishing of conciliar institutions in the years after 1689 - more frequent parliaments, the revival of convocation in England and Ireland, even the meeting of the convocation of the Stanneries - is illusory. In theory conciliar bodies would offer vehicles of consent and cooperation to support King William's wars; in practice, they often exposed divisions and delayed assent. The crises which came to the fore across Britain and Ireland in the years between 1698 and 1703 exposed the problems of conciliarism. It was no longer the appropriate or effective mechanism for managing the new fiscal-military state. ${ }^{81}$

The first two decades after the Revolution were liminal ones for counsel and councils. Debates in England and Scotland about evil counsel blended old complaints with new political languages. Buchanan bolstered claims for parliamentary power, Lauder Bridge sat alongside the Lockean contract, conciliarism with the Claim of Right, the ancient constitution with national interest. The overthrow of James II and VII eased the rhetorical slippage from denouncing evil counsel to endorsing deposition, and the clearer parliamentary sovereignty which ensued upon the various constitutional settlements of 1689 allowed for the revival of plans, unspeakable for thirty years because of their Civil War associations, for parliamentary

${ }^{80}$ State Papers ... addressed to Carstares, pp. 743-4.

${ }^{81}$ D. Hayton, 'Constitutional Experiments and Political Expediency, 1689-1725', in S. G. Ellis and S. Barber (eds), Conquest and Union: Fashioning a British State, 1485-1725 (Harlow, Longman, 1995). 
appointment of privy councillors. Yet that parliamentary authority was also the source of the decline of both councils and counsel. Post-revolutionary monarchs still had their advisers and favourites, but Portland, Sarah Churchill and Abigail Masham were not Buckingham, Leicester or Scheves. ${ }^{82}$ As William and Anne recognised, however reluctantly, the command of a parliamentary majority was increasingly necessary for political authority, especially in the circumstances of requiring regular taxation for war. Service, duty, even conscience and oaths were still cited by those giving advice, yet discussions of counsel sat uneasily with the new willingness to admit the paramount driving force of interest. Interest might lobby; it did not have to (pretend to) counsel.

Such changes also allowed the admission of the British problem: that England and Scotland might have competing interests which counsel could not necessarily reconcile. Throughout the seventeenth century various suggestions for joint British councils had been made, separate from or in addition to national councils, with or without mutual AngloScottish representation. The year after the parliaments incorporated, the Scottish privy council was abolished. Although concern was expressed about the legal, military and ecclesiastical implications of this - and particularly about the speed with which it was to take place - some welcomed the chance for Scotland to further incorporate itself. 'The arguments that are used for taking it away are plausible and popular here, such as, that of coming immediately into the English constitution', wrote Loudoun to Carstares in $1708 .{ }^{83}$ Loudoun had identified the voice of much eighteenth-century Scottish unionism: embracing the chance to go further than 1707 and forge legal union to update Scottish law, remove aristocratic

\footnotetext{
${ }^{82}$ On the illusory importance of bedchamber politics under Anne, see G. Holmes, British Politics in the Age of Anne (London, Hambledon, 1987), ch. 6.

${ }^{83}$ State Papers ... addressed to Carstares, p. 771; see also p. 767; Seafield Correspondence, pp. 436ff, 459.
} 
power and modernise the Scottish economy for a new imperial age. It was this mindset which embraced and praised Cromwellian conquest as an enlightened despotism which had fleetingly offered modern English institutions to Scotland $;{ }^{84}$ this mentality which first disowned the dynastic union of 1603 as one which failed to protect Scotland's interests, and which then forgot it, so 'the union' came to mean 1707.

Incorporating union got round rather than solved the problem of British counsel. It could be assumed that a British council and British parliament would provide for Scotland's voice alongside England's. Confederal or federal union under a shared monarch could only work if a systematic plan was made which provided for separate councils, mutual representation of each country on the other's council and joint bodies to resolve tensions between them. Counsel in a con/federal union brought to the fore the 'East Lothian Question' of the relative political weight of demographically and economically unequal partners. Devolution without systematic plans for coordinating the consent, consensusbuilding and management of political and geographical relationships which counsel could provide has created the West Lothian Question instead. Composite states might have been able to survive without carefully planned mutual and joint councils in the early modern period, because there was just enough informal counsel to hold them together, even at the cost of major tensions. Seventeenth-century Britons partly recognised, but could not solve, the problem of how to create a well-functioning system of British counsel and councils. How to do so remains crucial to rethinking British union in the twenty-first century.

\footnotetext{
${ }^{84}$ C. Kidd, 'Eighteenth-Century Scotland and the Three Unions', in Smout (ed.), Anglo-
} Scottish Relations, 171-87, at 182-5. 